\title{
GÖRSEL ODAKLANMADA KADIN VE ERKEKLER ARASI FARKLILIKLAR: BASILI REKLAM GÖRSELLERİ ÜZERİNE BİR ÇALIŞMA
}

\author{
DIFFERENCES BETWEEN MEN AND WOMEN IN FIXATION: \\ A STUDY ON PRINTED ADVERTISEMENT
}

Dicle Yurdakul ${ }^{\star}$
Yener Girişken $^{\star *}$

Öz

Kadınlar ve erkekler arasındaki algısal ve bilişsel farklılıkların ortaya konulması, pazarlama ve tüketici davranışları disiplinleri açısından büyük önem taşımakta, hedef kitlenin istek ve ihtiyaçlarına en doğru şekilde hitap edebilmek ve etkin bir iletişim kurabilmek için anahtar rol oynamaktadır. Bu çalışmada, reklam görselleri üzerinden kadın ve erkekler arasındaki görsel odaklanma farklılıklarının ve dolayısı ile kadın ve erkek tüketicilere ulaşmada görsellerin hangi öğelerinin ve bölgelerinin daha büyük önem teşkil ettiğinin tespit edilmesi amaçlanmıştır. Farklı alanlarda yapılmış önceki çalışmalarda, kadın ve erkeklerin bu eğilimlerine ilişkin bulgulara rastlanmakla birlikte, bu farklılıkların pazarlama alanında ve reklam görselleri üzerinde test edildiği çalışmaların sayısı oldukça kısıtlıdır. Literatürdeki bu eksiklik göz önüne alınarak, 117 katılımcı ile gerçekleştirilen göz tarama (eye-tracking) çalışması sonucunda, kadın ve erkeklerin odaklanma örüntülerinin farklı olduğu ve farklı görsel öğelere odaklanma eğilimi gösterdikleri tespit edilmiştir. Bu bulguların pazarlama iletişimi tasarımında kullanılması iletişim etkinliğinin arttırılması açısından son derece önemli sonuçlar doğurabilecek niteliktedir.

Anahtar Kelimeler: Göz taraması, görsel odaklanma, cinsiyet, iletişim, reklam

\begin{abstract}
Manifesting the perceptual and cognitive differences between men and women is of key importance for the disciplines of marketing and consumer behavior, specifically in addressing the needs and demands of the target market in the most accurate way and establishing effective communications with them. In this study, we aim to determine the visual fixation differences between men and women through advertising images, and to identify which elements and regions of the visuals are of greater

* Asst. Prof. Dr., Altınbaş University, School of Business Administration, Department of Business Administration, dicle.yurdakul@altinbas.edu.tr

** Asst. Prof. Dr., Altınbaş University, School of Business Administration, Department of Business Administration, yener.girisken@altinbas.edu.tr
\end{abstract}


importance in reaching the male and female consumers. Even though the the previous studies in different disciplines report findings about this tendency, the number of studies in the marketing field in which these differences have been tested on advertisements is rather limited. Considering this gap in the literature, the findings of the eye-tracking study conducted with 117 participants reveal that, visual fixation patterns of men and women are different, and they tend to focus on different items in the visuals. The use of these findings in the design of marketing communications may have important consequences in enhancing communication effectiveness.

Keywords: Visual tracking, visual fixation, gender, communications, advertisement

\section{Giriş}

Görsel odaklanma, hem tüketicilerin farklı amaçları ve öncelikleri gibi içsel faktörlerin, hem de görsel uyaranın özellikleri gibi dışsal faktörlerin etkileşimi ile gerçekleşen karmaşık bir süreçtir. Odaklanma ile bilişsel süreçler ve hafıza arasındaki doğrudan ilişki, kavramın pazarlama ve tüketici davranışları alanları açısından önemini açıkça gözler önüne sermektedir. Öte yandan, tüketicilerin herhangi bir görselin öğelerine ve farklı bölgelerine ne kadar süre ile odaklandıklarını tespit etmek, pazarlama uzmanları ve reklamcılar açısından, bu görsellerin tasarlanması sürecinde anahtar rol oynamaktadır. Beyana dayalı olarak gerçekleştirilen hatırlama testleri gibi geleneksel yöntemler, karmaşık odaklanma süreçleri ve bu süreçlerin arkasındaki mekanizmaları açıklamada yetersiz kalmakta, bu nedenle söz konusu alanda yenilikçi yöntemlere ihtiyaç duyulmaktadır.

Göz tarama (eye-tracking) yöntemi son yıllarda farklı disiplinlerde sıklıkla kullanılan yöntemlerden biri olup, pazarlama ve tüketici araştırmalarındaki uygulamaları da gün geçtikçe yaygınlaşmaktadır. Görsel odaklanmanın disiplinimiz açısından önemi göz önüne alındığında, bu süreci etkileyen içsel ve dişsal değişkenlerin ve etki mekanizmalarının tespitinin pazarlama akademisyenleri ve uygulamacıları açısından çok değerli bilgiler üreteceği aşikardır. Bugüne kadar yapılan çalışmalarda her iki grup faktör de incelenmekle birlikte, içsel faktörlere dair araştırmaların sayı ve içerik olarak kısıtlı kaldığı görülmektedir (Wedel ve Pieters, 2008).

Literatürdeki bu eksiklik göz önüne alınarak, bu araştırma kapsamında, araştırmada kullanılmak üzere hazırlanan görseller ile outdoor reklamlar üzerinden göz tarama verileri elde edilerek, kadınların ve erkeklerin göz hareketleri ve odaklanma örüntüleri arasındaki olası farklılıkların tespit edilmesi amaçlanmıştır. Tüm görsel iletişim çabalarının temelinde yatan ve iletişimin başarılı bir şekilde gerçekleştirilmesi için olmazsa olmaz kabul edilen hedef kitleyi yakından tanıma gerekliliği bu çalışma ile bir adım öteye taşınmaktadır. Yapılan göz tarama çalışmasının sonuçları, kadın ve erkek hedef kitle grupları ile en etkin iletişimi kurmak için kullanılacak görsellerin ne şekilde tasarlanması gerektiğine dair çok önemli bilgiler sunarak, pazarlama, tüketici davranışları, medya ve iletişim literatürlerine katkıda bulunmaktadır.

Tüm görsel iletişim çabalarının temelinde yatan ve iletişimin başarılı bir şekilde gerçekleştirilmesi için olmazsa olmaz kabul edilen hedef kitleyi yakından tanıma gerekliliği bu çalışma ile bir adım 
öteye taşınmaktadır. Yapılan göz tarama çalışmasının sonuçları, kadın ve erkek hedef kitle grupları ile en etkin iletişimi kurmak için kullanılacak görsellerin ne şekilde tasarlanması gerektiğine dair çok önemli bilgiler sunarak, pazarlama, tüketici davranışları, medya ve iletişim literatürlerine katkıda bulunmaktadır.

\section{Literatür Analizi}

Göz hareketleri görsel dikkat sürecinin kesin bir göstergesidir. Bu bilgiye dayanarak, göz tarama yöntemi, pazarlama araştırmaları alanında sıklıkla kullanılan yöntemlerden biri haline gelmiştir. Göz tarama yöntemi ile elde edilen temel verilerden biri olan odaklanma (fixation) gözün belirli bir süre (200-500 milisaniye) belirli bir noktaya sabitlenmesi anlamına gelmektedir. Literatürdeki çalışmalar odaklanma ile hafıza ve tercih davranışı arasındaki ilişkiyi ortaya koymuştur. Buna göre daha uzun süre odaklanılan alternatifler kişilerin nihai tercihleri olarak karşımıza çıkmaktadır (Chandon ve diğerleri, 2009; Schotter ve diğerleri, 2010). Odaklanma ile tercih arasındaki bu ilişki, göz tarama yönteminin ve odaklanma verisinin pazarlamacılar açısından önemini bir kez daha vurgulamaktadir.

Göz tarama yöntemi kullanılarak alternatifler arasında tercih yapma (van Raaij, 1977), tercih süreci (Russo and Leclerc, 1994), görsel dikkat ile marka tercihi ilişkisi (Pieters ve Warlop, 1999), POP pazarlamanın marka tercihi üzerindeki etkisi (Chandon ve diğerleri, 2002), reklam içeriklerinde büyüklük, font, renk ve görsellerin etkileri (Lohse, 1997), görsellerde kullanılan öğelerin yerleşimi ve marka genişletme faaliyetlerinin yarattığı etkiler (Stewart, Pickering, ve Sturt, 2004) ve marka hatırlama (Pieters, Warlop, ve Wedel, 2002) gibi pek çok alanda araştırmalar yapılmıştır. Pazarlama araştırmalarında ortaya konulan bu çalışmaların yanı sıra, göz tarama yöntemi sosyal pazarlama ve kamu politikaları alanlarında da sıklıkla kullanılmaktadır. Sigara paketleri ve alkollü içeceklerin etiketleri üzerinde yer alan zorunlu sağlık mesajlarına ve besleyicilik değerlerini gösteren tablolara, tüketicilerin ve özellikle gençlerin ne kadar dikkat ettiğinin tespiti, ve alkollü ürünlerin reklamlarının etkilerinin anlaşılması gibi çalışmalarda da göz tarama yöntemi sıklıkla kullanılmıştır (Fox ve diğerleri, 1998).

$\mathrm{Bu}$ çalışmalarda kimi zaman görsellerin odaklanma ve dikkat üzerindeki etkisi araştırılırken, kimi zaman da bireysel özelliklerin bu süreçleri ne şekilde etkilediği üzerinde durulmuştur. Bu araştırma kapsamında, göreceli olarak daha az çalışmanın konusu olan ikinci alana odaklanılarak, cinsiyet değişkeninin odaklanma süreçleri üzerindeki etkisi ve kadınlar ile erkekler arasındaki olası görsel odaklanma farklılıkları üzerinde durulacaktır.

Kadın ve erkekler arasındaki çeşitli farklılıklar ve bu farklılıkların davranışsal boyuttaki yansımaları pek çok farklı bilim dalında, çok sayıda araştırmaya konu olmuştur. Bu araştırmaların sonucunda, mevcut farklılıkların temel nedenlerini biyolojik ve sosyolojik nedenler olarak iki ana gruba ayırmak mümkündür. Biyolojik nedenler doğumdan itibaren, herhangi bir sosyal öğrenme sürecine maruz kalmadan da varlığı ispat edilebilen farklılıkları ifade etmekte iken, sosyolojik 
nedenler ise sosyalleşme süreci beraberinde gelişen öğrenme dolayısı ile ortaya çıkan, sonradan geliştirilen ve cinsiyet rollerini şekillendiren farklılıkları ifade etmektedir.

Kadın ve erkeklerin çeşitli görsel uyaranlara farklı tepkiler vermelerine ilişkin gerçekleştirilen göz tarama çalışmalarında da biyolojik ve sosyolojik nedenler ayrımı göze çarpmaktadır. Örneğin, çocukların oyuncak tercihleri üzerine yapilan çalışmalarda, cinsiyet nedeniyle ortaya çıkan farklılıkların doğum ile beraber gelen farkllıklar olduğuna yönelik bulgulara erişilmiştir. Henüz cinsiyete ilişkin bir farkındalığın ve cinsiyet rollerine dair bir öğrenmenin gelişmediği 3 ila 8 aylık bebekler ile gerçekleştirilen göz tarama çalışmasında, görsel yönelimde kız bebeklerin oyuncak bebeğe, erkek bebeklerin ise oyuncak kamyona yöneldikleri tespit edilmiştir (Alexander, Wilcox, ve Woods, 2009). Bebeklerin oyuncak tercihlerinin hayatlarının ilerleyen evrelerinde cinsiyete ilişkin bilişsel yetiler ve kişisel özelliklerin gelişmesindeki rolü düşünüldüğünde (Connor ve Serbin, 1977; Robert ve Heroux, 2004; Eisenberg, Murray, ve Hite, 1982), bu süreçlerin biyolojik faktörler tarafından şekillendiriliyor olmasının ortaya çıarılması büyük önem arz etmektedir. Cinsiyet rollerine ve bu roller içinde nasıl davranılması gerektiğine dair öğrenme süreci, çocukluktan itibaren bireylerin etraflarındaki dünyayı algılama ve anlamlandırma biçimlerini şekillendirmede en önemli faktörlerden biridir (Martin, Ruble, ve Szkrybalo, 2002).

Öte yandan, doğumdan kısa bir sure sonra kız bebekler insan yüzü hareketlerine, erkek bebekler ise mekanik bir düzeneğin hareketlerine daha yoğun bir görsel dikkat göstermektedir (Connellan, Baron-Cohen, Wheelwright, Batki, ve Ahluwalia, 2000; Lutchmaya ve Baron-Cohen, 2002). Benzer şekilde, 12-24 aylık bebeklerde anne ile göz temasının kız bebeklerde daha uzun süreli olduğu ve göz temasının prenatal testosteron seviyeleri ile korelasyon gösterdiği ortaya konulmuştur (Lutchmaya, Baron-Cohen, ve Raggatt, 2002). Bu tercihlerin cinsiyet rollerine biyolojik bir taban teşkil ederek, örneğin, kadınlarda insan formuna ve yüzüne ilgi ile bebeğe karşı geliştirilen annelik duygusuna bir ön hazırlık oluşturabileceği ve dolayısı ile üreme başarısını arttırmaya yönelik içsel bir motivasyon olabileceği tartışılmaktadır (Alexander, Wilcox, ve Woods, 2009).

Benzer şekilde, yetişkinlerle yapılan çalışmalarda da görsel dikkatin kadın ve erkeklerde farklı öğeler üzerinde toplandığına dair önemli bulgulara ulaşılmıştır. Bu yöndeki çalışmalarda gösterilen görseller arasından kadınların insan figürlerini, erkeklerin ise mekanik objeleri daha yüksek oranlarda hatırladıkları (McGuinness and Symonds, 1977), yüz tanıma sürecinin erkeklerde daha geç tamamlandığı (Taylor ve diğerleri, 2001) ve kadınların gördükleri yüzleri tanıma açısından özellikle hemcinslerinin yüz görsellerini tanıma bağlamında erkeklerden anlamlı derecede farklı bir üstünlüğe sahip oldukları (Cross, Cross, ve Daly, 1971; Lewin ve Herlitz, 2002; Wright ve Sladden, 2003; Armony ve Sergerie, 2007) sonuçlarına ulaşılmıştır. Odaklanma ve hafıza arasındaki ilişki dikkate alındığında (Wedel ve Peters, 2000), kadınların söz konusu görsellere daha fazla odaklandıkları sonucuna varılmaktadır. Daha önce bahsi geçen çalışmalarda bu farklılıkların biyolojik kaynaklı olabileceğine dair elde edilen bulgular nedeni ile, bebeklik döneminde ortaya çıan bu farkların yetişkinlik dönemindeki bilişsel süreçleri de etkilediğinden bahsetmek mümkündür (Bayliss, di Pellegrino, ve Tipper, 2005). 
Söz konusu çalışmalar medya ve iletişim literatüründe de karşılık bulmuş ve kadınlar ile erkekler arasında görsel dikkat, odaklanma, beğeni ve tercih anlamında farklılıklar olduğu ileri sürülmüştür. Bu araştırmalarda, zaman zaman çelişkili bulgulara rastlanmakla beraber, kadınların erkeklere kıyasla reklam içeriklerindeki metinlere, erkeklerin ise fotoğraflara ve ikonlara daha uzun süre odaklandıkları ve estetik tercihlerinin farklı olduğu (Moss and Colman, 2001), web içeriklerinde renk ve görsel kullanımına ilişkin tercihlerinin farklılaştığ (Moss ve diğerleri, 2006; Tedesco ve diğerleri, 2004) ve görsel açıdan kendi cinsiyetlerine mensup kişiler tarafından tasarlanmış ürünleri tercih etme eğiliminde oldukları ortaya konulmuştur (Moss ve Colman, 2001; Djamasbi ve diğerleri, 2007).

$\mathrm{Bu}$ araştırmanın temel amacı, kadınlar ve erkekler arasındaki söz konusu farklılıklardan yola çıkarak, her iki kitlenin farklı görsel uyaranlara verdikleri farklı tepkilerin, odaklanma sürelerinin ve örüntülerinin tespit edilmesidir.

\section{Tasarım ve Yöntem}

Göz tarama yöntemi ile izlenen göz hareketleri gözün farklı bölgeler arasında hızla gezinmesi (saccade) ve belirli bir bölgeye odaklanması (fixation) hareketlerinden oluşmaktadır. Göz tarama yönteminde kişilerin başlarına ya da karşılarındaki ekrana yerleştirilen kameralar aracılığı ile göz hareketleri izlenerek odaklanma ve gezinme hareketleri kaydedilmektedir. Kızılötesi korneal yansıtma metodolojisi ile gözbebeğinin hareketleri kayıt altına alınarak, tarama ve 1sı haritaları oluşturulmaktadır. Odaklanma gözün göreli olarak sabit kaldığı durumlardır ve farklı kaynaklarda farklı rakamlarla ifade edilmekle birlikte, 200-500 milisaniye aralığında gerçekleşmektedir (Rayner, 1998; Wedel ve Pieters, 2008). Odaklanma ile elde edilen görsel veri beyin tarafindan işleme tabi tutulan veridir. Beyinsel kapasite optik sinirler aracılığı ile iletilen tüm veriyi işlemeye müsait değildir. Bu nedenle devreye giren seçici dikkat süreci, görselin yalnızca belirli bir kısmının ileri seviyede işleme tabi tutulmasına ve seçili olmayan bölgelerin baskılanmasına neden olur (Wedel ve Pieters, 2008). Odaklanma dikkatin tek unsuru olmamasına karşın, hafıza ile kurulan bağlantıyı göstermesi açısından anahtar önemdedir (Wedel ve Peters, 2000).

$\mathrm{Bu}$ araştırma toplamda 117 kişi ile gerçekleştirilmiş olup, katılımcılar \%50 kadın \%50 erkek olmak üzere 15 - 55 yaş arasındaki Türkiye profiline uygun olarak, farklı eğitim ve gelir gruplarına mensup kişiler arasından seçilmiştir. Araştırma örneklemi mevcut katılımcı havuzundan ilgili kriterler doğrultusunda getirilen kotalar aracılığı ile rastsal olarak seçilmiştir. Ölçülen görsellerin bir kısmı araştırma ekibi tarafından üretilirken, bir kısmı da Beşiktaş-Levent hattı üzerindeki outdoor reklam panolarından oluşturulmuştur.

Araştırma verileri kişilerin başlarına ya da karşılarındaki ekrana yerleştirilen kameralar tarafından kaydedilen gözün odaklanma ve gezinme hareketlerinin sürelerinin milisaniye cinsinden ölçülmesi yolu ile toplanmıştır. Kızılötesi korneal yansıtma metodolojisi kullanılarak kayıt altına alınan gözbebeği hareketi verileri üzerinden ortalama odaklanma süreleri ve odaklanma yüzdeleri hesaplanarak tarama ve ısı haritaları oluşturulmuştur. Hazırlanan görsellerde özellikle 
«Heatmap» (1sı haritası) ve görsel üzerindeki seçilen alanı katılımcıların ne kadarının gördügü gösteren «Percentage Fixated» (odaklanma yüzdesi) analizleri uygulanmıştır. Outdoor reklam panolarında ise seçilen alanda ne kadar süre boyunca odaklanma olduğunu gösteren «Total Fixation Duration» (toplam odaklanma süresi) analizleri de ek olarak uygulanmıştır. Araştırma bulguları, bir sonraki bölümde ısı haritaları ile odaklanma yüzdesi ve toplam odaklanma sürelerini ifade eden grafikler aracılığıyla tartışlacaktır.

\section{Bulgular}

Kadın ve erkekler arasında, görsellerin farklı öğelerine ve bölgelerine odaklanmadaki farklılıkların tespiti amacı ile, araştırma için hazırlanan ya da outdoor reklam panolarından oluşturulan, kadın ve erkek yüzleri ile logo, slogan ve diğer yazıları içeren görseller kullanılmıştır. Kadın ve erkeklerin hemcinslerinin yüzlerine daha fazla odaklanma eğilimleri düşünülerek her iki cinsiyete ait yüz görselleri ölçümlere dahil edilmiştir. Ayrıca kadın ve erkeklerin genel odaklanma örüntülerinin tespit edilebilmesi için farklı öğeler içeren görseller kullanılmış, böylece görüntü alanı içerisinde yer alan tüm bölgelere ait odaklanma verileri de elde edilmiştir.

Öncelikli olarak, görsellerde yer alan kadın ve erkek yüzlerine odaklanma eğilimlerinin tespiti amacı ile benzer tasarımlı 4 görsel kullanılmıştır. Görsellerin ikisi kadın, ikisi erkek manken içermekte, bir görselde kadın veya erkek karşıya bakarken diğer görselde gözle yönlendirme etkisinin ölçülebilmesi amacı ile logoya bakmaktadır.
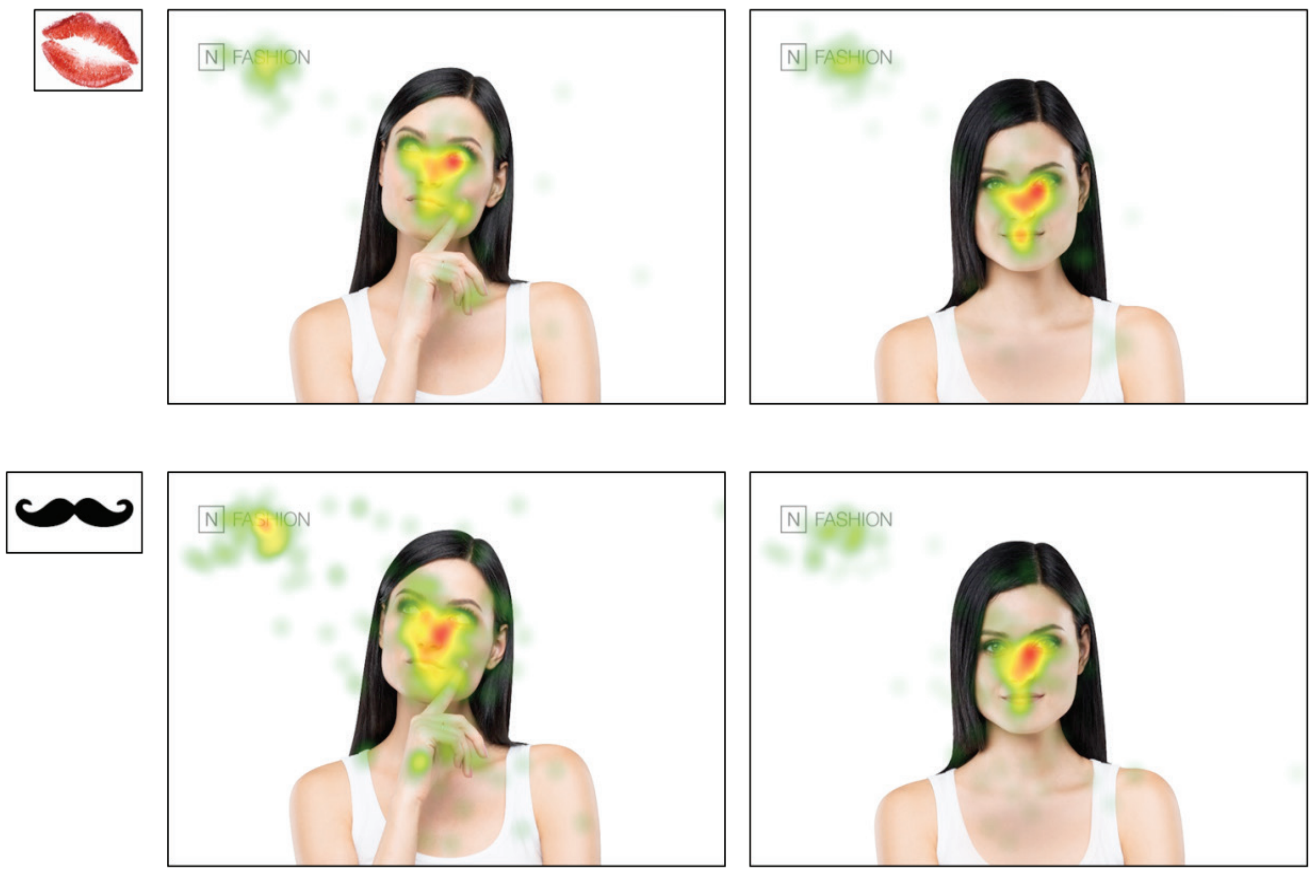

Şekil 1: Kadın Manken ve Logo İçeren Tasarım için Isı Haritaları 
Isı haritası bulgularına göre, kadınlar her iki görselde de hem yüze hem de logoya odaklanırken, erkeklerin de yüze odaklandıkları, ancak kadın mankenin logoya baktığı görselde bakış yönünü takip etme ve daha geniş bir alanı tarama yönünde eğilim gösterdikleri görülmektedir.
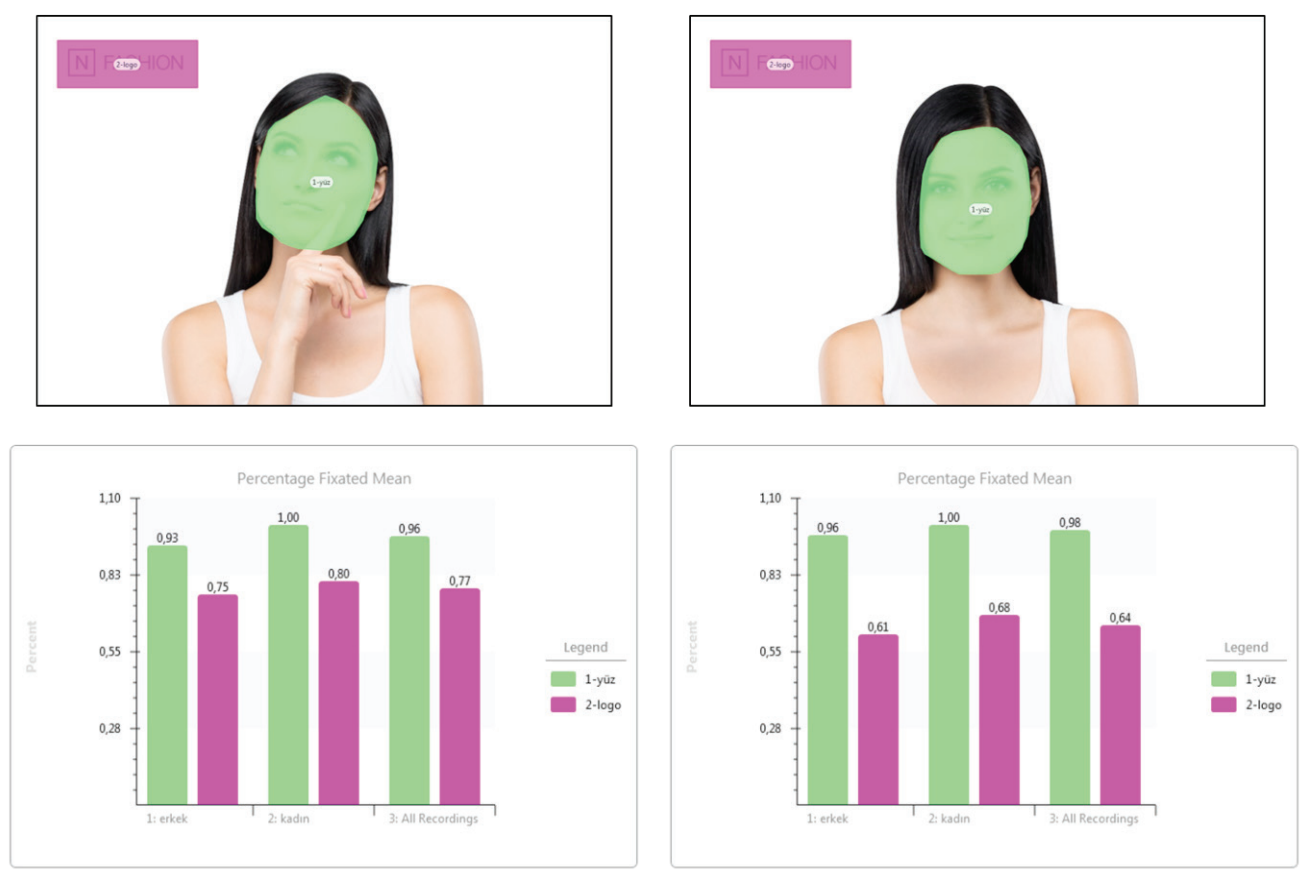

Şekil 2: Kadın Manken ve Logo İçeren Tasarım için Ortalama Odaklanma Yüzdesi (Percentage Fixated Mean) Grafikleri

Ortalama odaklanma yüzdesi verilerine bakıldığında, her iki görsel için kadınlar erkeklere kıyasla yüze ve logoya daha yüksek oranda odaklanma göstermişlerdir. Bu bulgular, kadınların gerek biyolojik gerek sosyolojik nedenlerle insan formu ve yüze odaklanma, ve aynı zamanda hemcinslerinin yüzlerine daha fazla odaklanma ve daha fazla tanıma eğilimlerine dair önceki çalışma bulgularını destekler yöndedir (Lutchmaya ve Baron-Cohen, 2002; Cross, Cross, ve Daly, 1971; Lewin ve Herlitz, 2002; Wright ve Sladden, 2003; Armony ve Sergerie, 2007).

Benzer tasarımlı görsellerde erkek manken kullanımında ise farklı bulgulara ulaşıldığı görülmüş̧ür. 

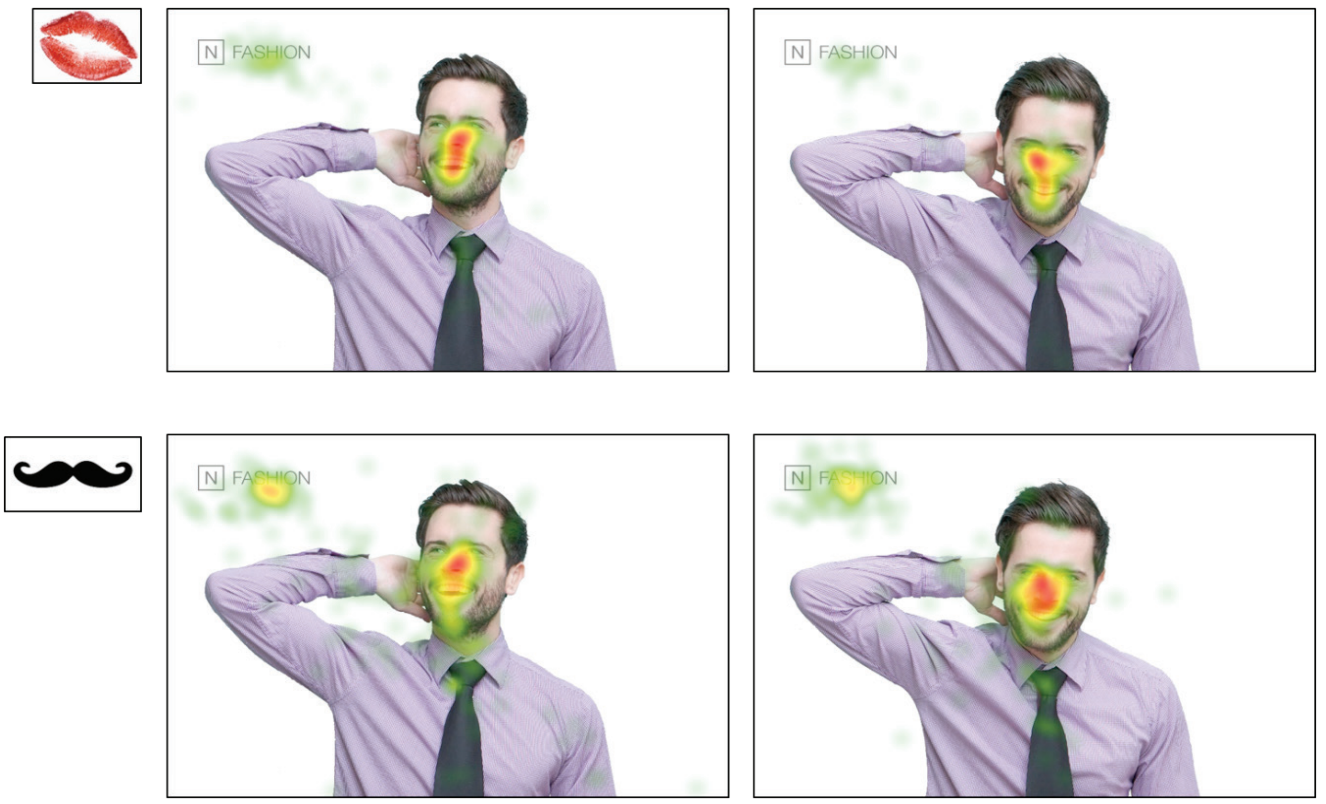

Şekil 3: Erkek Manken ve Logo İçeren Tasarım için Isı Haritaları
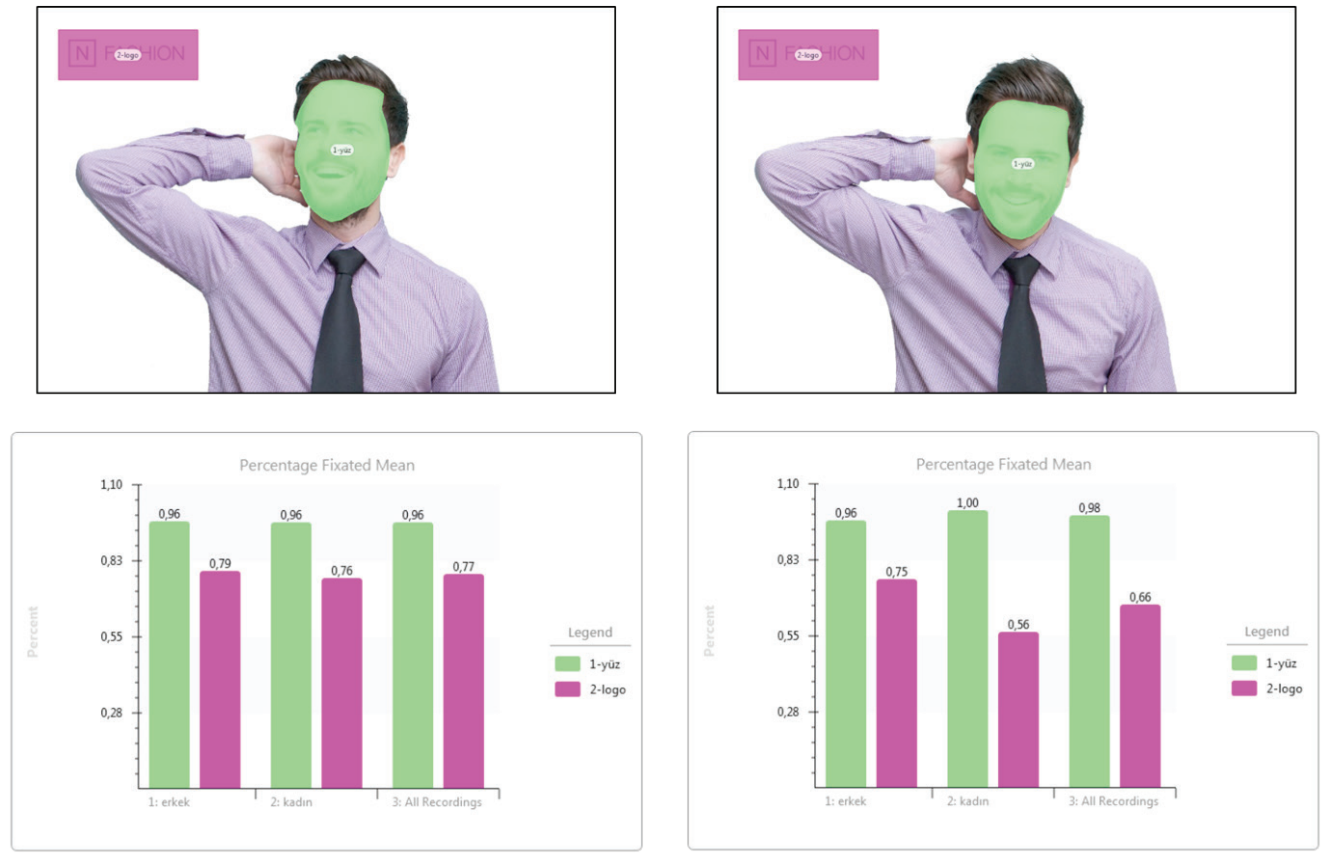

Şekil 4: Erkek Manken ve Logo İçeren Tasarım için Ortalama Odaklanma Yüzdesi (Percentage Fixated Mean) Grafikleri 
Isı haritası bulgularına göre erkeklerin yine bakış yönünü takip etme ve daha geniş bir alanı tarama yönünde eğilim gösterdikleri, öte yandan mankenin logoya baktığı görselde yüze odaklanma yüzdesinin kadınlarla aynı olduğu $(0,96)$ görülmektedir. Mankenin karşıya baktığı görselde kadınların yüze odaklanma oranı daha fazladır. Bireylerin hemcinslerinin yüzlerine odaklanma yönünde eğilim gösterdiklerine dair önceki çalışma bulguları, bu görsellerde mankenin logoya baktığı görsel için kısmen doğrulanmış olsa da, ikinci görsel için yine kadınların daha yüksek oranda yüze odaklanma gerçekleştirdikleri görülmektedir. Diğer yandan, kadın mankenin yer aldığ 1 görsellerin aksine, bu görsellerde erkeklerin logoya odaklanma oranının her iki görsel için de kadınlara kıyasla daha yüksek olduğu, mankenin karşıya baktığı görselde ise odaklanma farklılığının oldukça belirginleştiği görülmektedir. Bu, literatürde yer alan erkeklerin ikon ve logolara daha fazla odaklandıklarına dair bulgu ile örtüşmektedir (Schiesel ve diğerleri, 2003). Ancak bu bulgunun önceki ölçümde elde edilen bulgular ile çelişiyor olması nedeni ile bu farklılıkların hangi değişkenlerin etkisi altında gerçekleştiği ile ilgili araştırmalar yapılması gerekliliğini de ortaya koymaktadır.

Bir sonraki ölçümde, görsel üzerindeki uyaranların sayısının odaklanmaya ilişkin farklı sonuçlar elde edilmesine sebep olup olmayacağının araştırılmıştır.

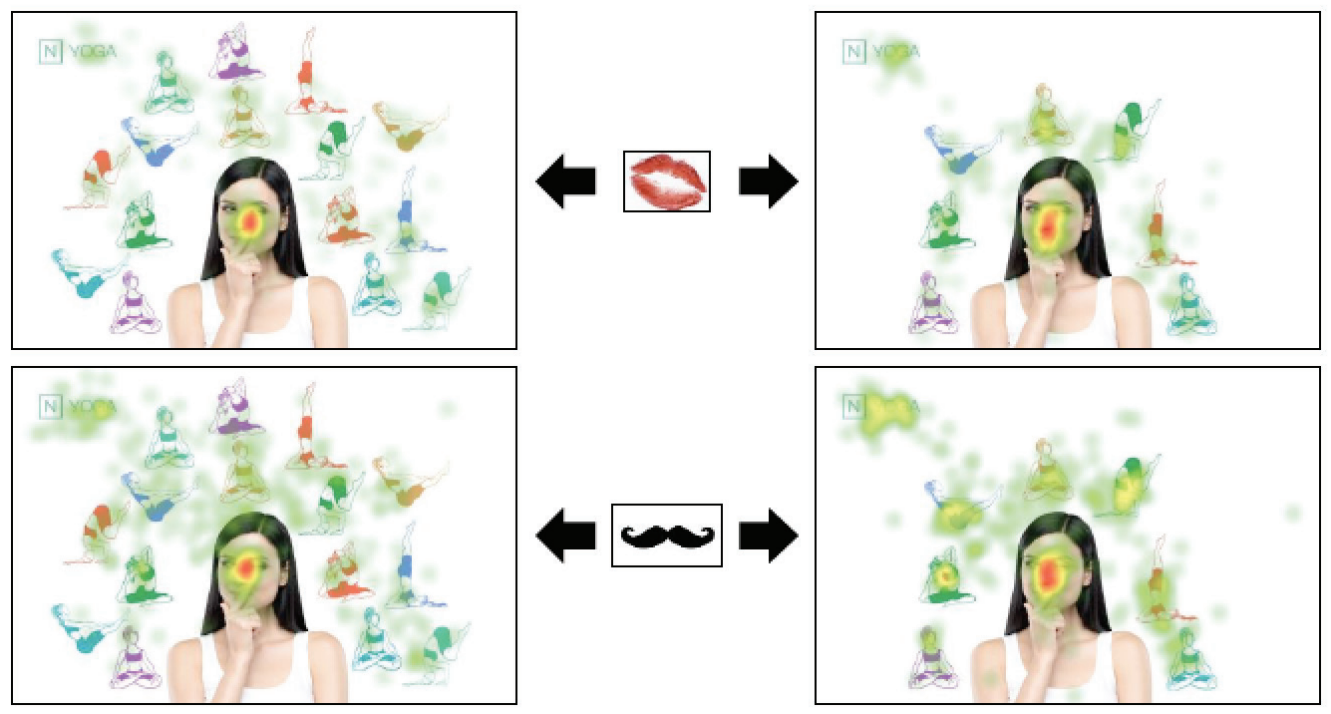

Şekil 5: Çoklu Uyaran İçeren Tasarımlar için Isı Haritaları

Isı haritaları, daha önceki görsellerde olduğu gibi erkeklerin kadınlara nazaran görselin daha geniş bir bölgesini taradıklarını ve uzamsal dikkat (Kimura, 1992) eğiliminde olduklarını göstermektedir. 

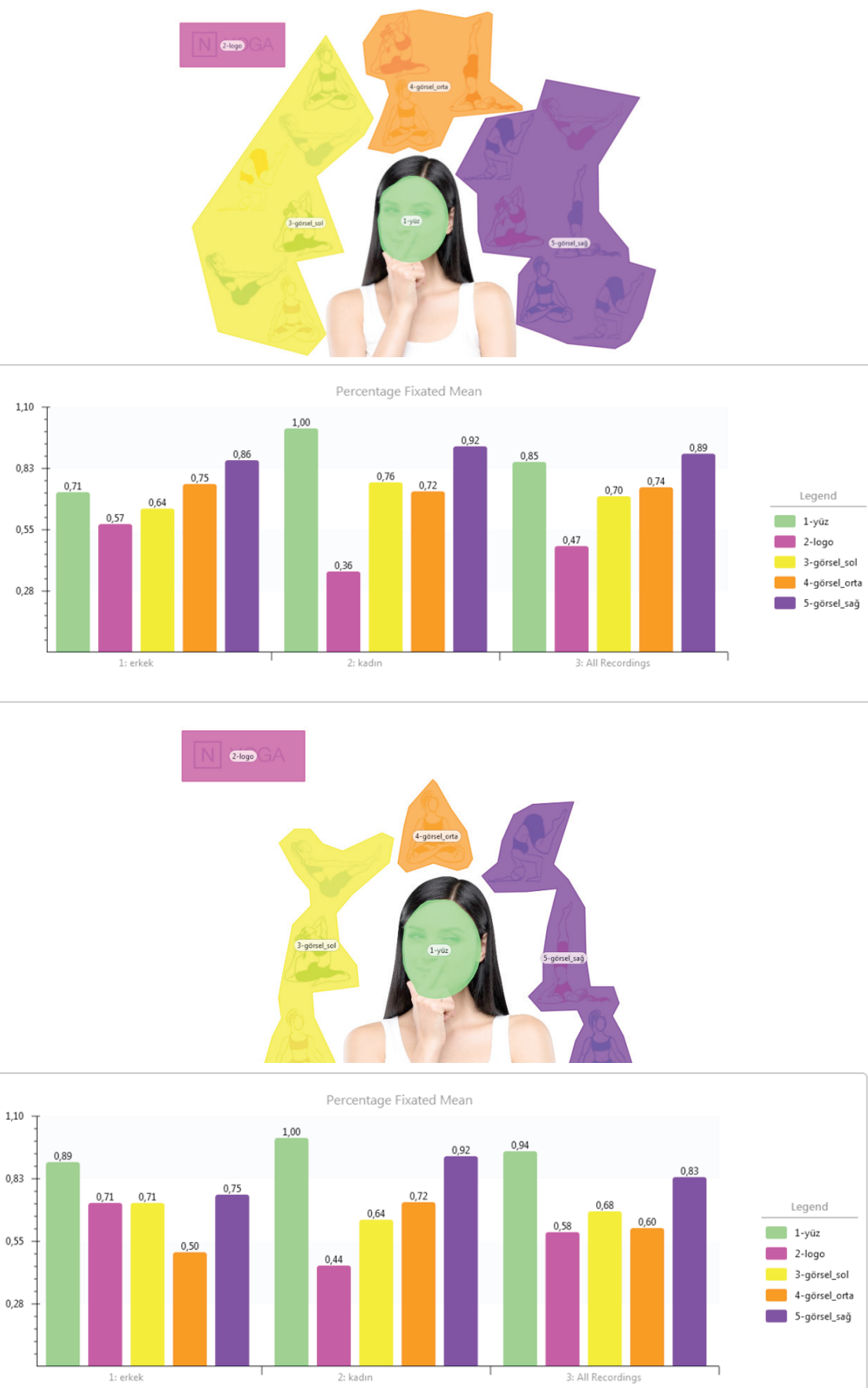

Şekil 6: Çoklu Uyaran İçeren Tasarımlar için Ortalama Odaklanma Yüzdesi (Percentage Fixated Mean) Grafikleri 
Önceki bulgular ve teori ile uyumlu bir şekilde, çoklu uyaran içeren tasarımlarda da kadınların yüze, erkeklerin ise logoya karşı cinse kıyasla daha yüksek oranda odaklanma gösterdikleri tespit ve teyit edilmiştir.

Bu bulguların ışı̆̆ında, göz tarama verileri kullanılarak katılımcıların outdoor reklam panolarında yer alan görsellerin farklı öğelerine ne kadar süre ile odaklandıklarını ifade eden toplam odaklanma süresi (total fixation duration) analizleri de ek olarak uygulanmıştır. Bunun için biri kadın biri hem kadın hem erkek olmak üzere üç tanınmış simanın yer aldığı outdoor reklam görselleri seçilerek, her iki görsel için toplam odaklanma süresi analizleri gerçekleştirilmiştir.
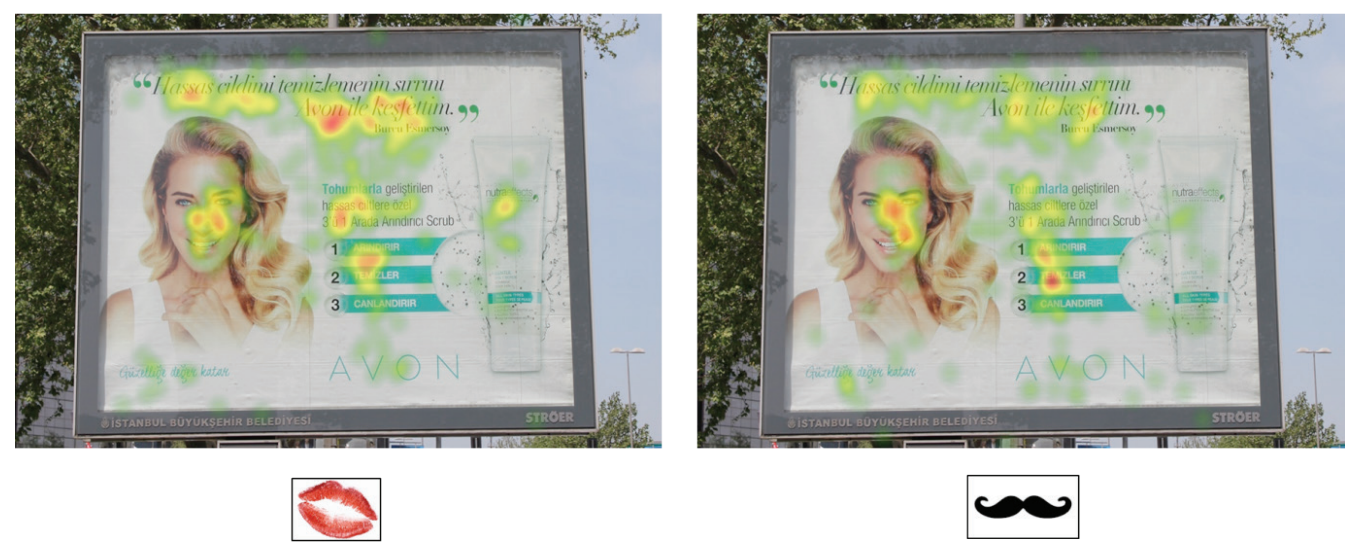

Şekil 7: Outdoor Reklam (Kadın) Isı Haritaları

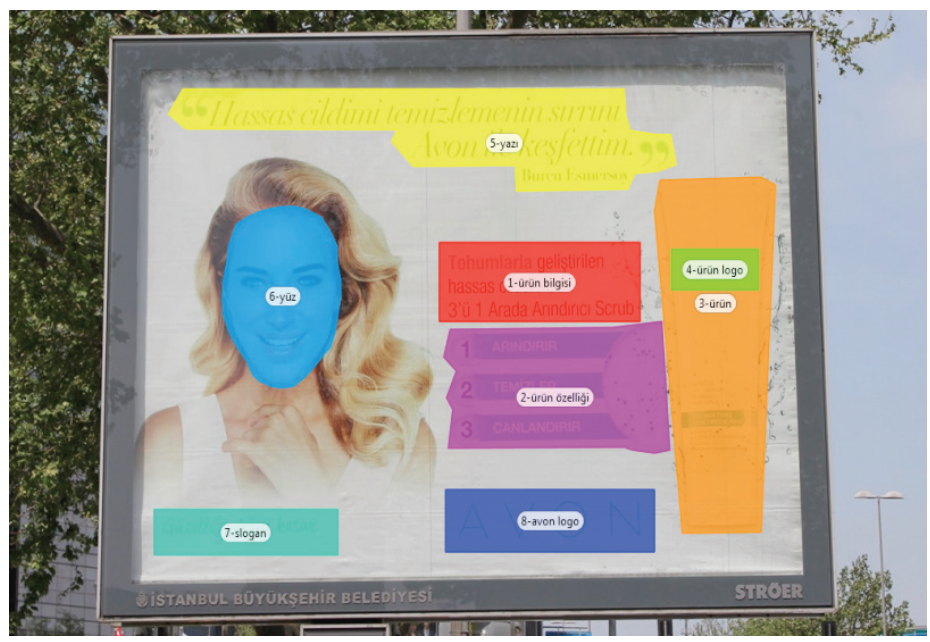




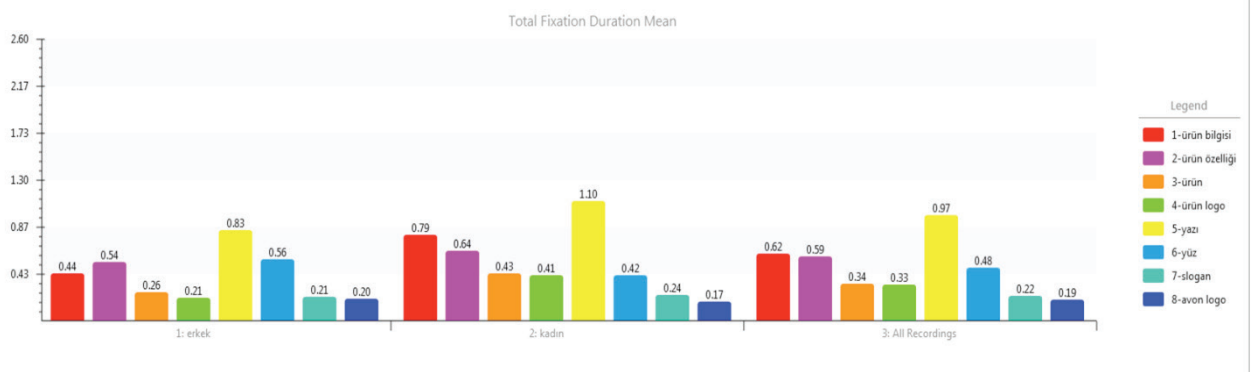

Şekil 8: Outdoor Reklam (Kadın) Toplam Odaklanma Süresi Grafikleri

Kadın ünlünün ve logo, yazılar, ürün ve slogan gibi çoklu uyaranların yer aldığı görsellerde, kadınlar ve erkeklere ait $1 s 1$ haritaları önceki ölçümlerle paralel bulguları işaret etmektedir. Öte yandan, toplam odaklanma süresi analizlerinde, erkeklerin kadınlara kıyasla yüze daha uzun süre odaklandıkları görülmüştür. Bu bulgu, kadınların erkeklere kıyasla tüm yüz görsellerine veya hemcinslerinin yüzlerine daha yüksek oranda ve daha uzun süre ile odaklanacaklarına dair önceki çalışma bulguları ile çelişir niteliktedir. Erkekler logoya daha uzun süre odaklanırken, slogan, yazı, ürün bilgisi ve ürün özelliği gibi yazılı materyallere daha kısa süre ile odaklanmaktadırlar. $\mathrm{Bu}$ noktada devreye giren bir diğer önemli husus, markanın ve ürünün hedef kitlesidir. Söz konusu görselde hedef kitlenin kadınlar oluşunun farklı öğelere farklı odaklanma süreleri atfedilmesinde nasıl bir katkısı olabileceği araştırılmaya değer bir başka husus olarak karşımıza çıkmaktadır.

Görselde yer alan ünlünün cinsiyetinin sonuçlar üzerinde herhangi bir etkisi olup olmadığının araştırılması amacı ile sonraki ölçümde bir kadın ve bir erkek ünlünün yer aldığı outdoor reklam görseli kullanılmıştır.
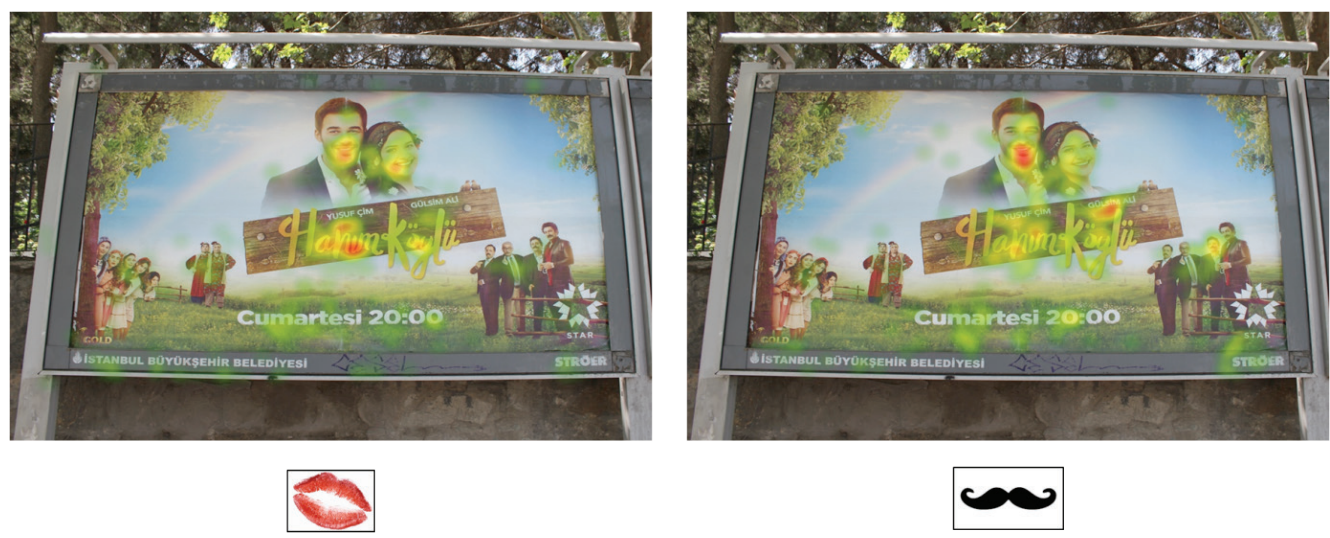

Şekil 9: Outdoor Reklam (Kadın ve Erkek) Isı Haritaları 

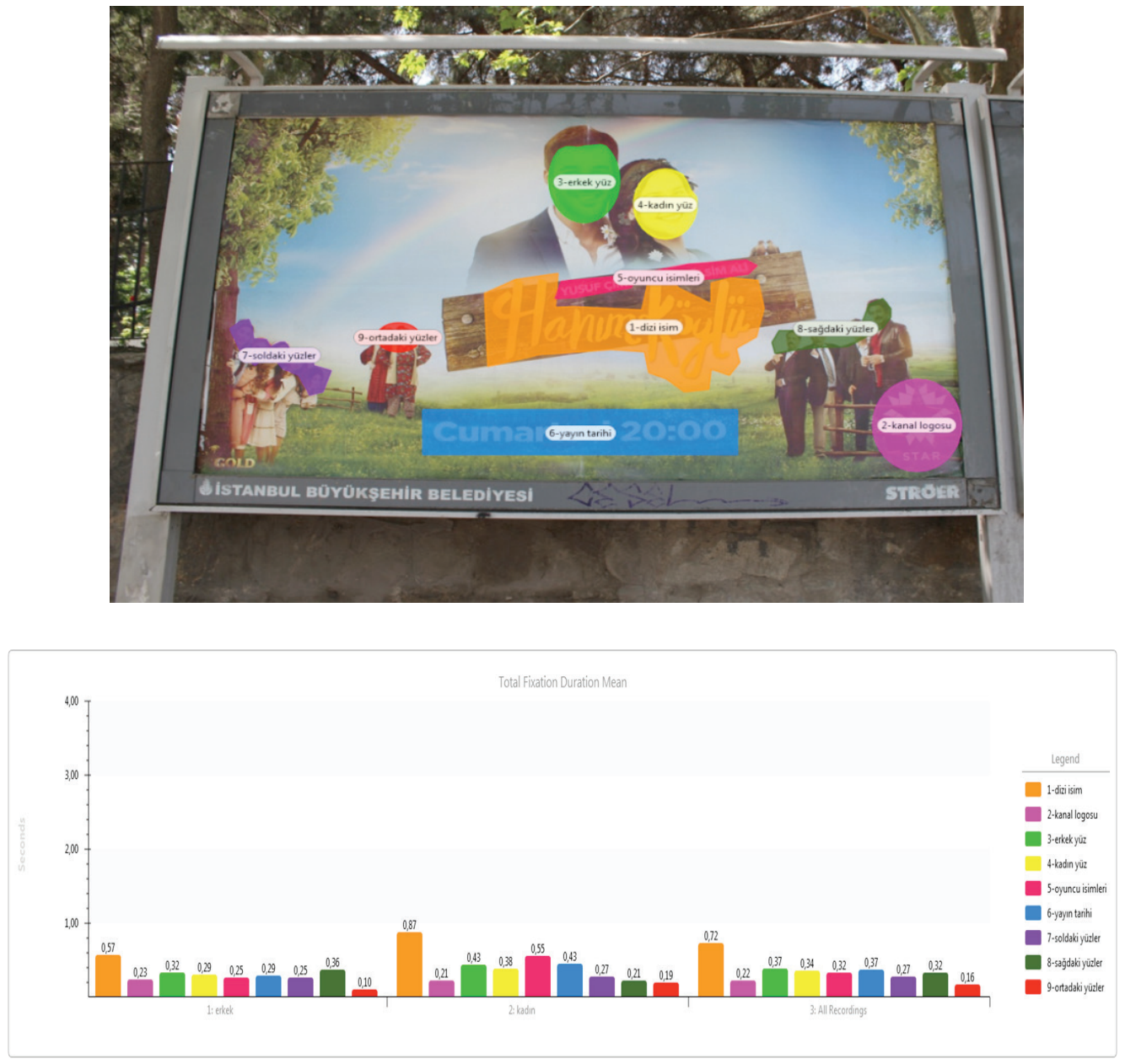

Şekil I0: Outdoor reklam (kadın ve erkek) toplam odaklanma süresi grafikleri

Isı haritalarından elde edilen benzer bulguların yanı sıra, toplam odaklanma süresi grafiklerine bakıldığında kadınların hem erkek hem kadın ünlünün yüzüne daha uzun süre odaklandıkları, erkeklerin ise bir önceki bulgular ile paralel olarak logoya daha uzun süre, yazılı materyallere ise daha kısa süre ile odaklandıkları tespit edilmiştir.

\section{Sonuç ve Öneriler}

Kadınlar ve erkekler arasındaki algısal ve bilişsel farklılıkların ortaya konulması, pek çok alanda olduğu gibi pazarlama disiplini açısından da büyük önem taşımakta, hedef kitlenin istek ve ihtiyaçlarına en doğru şekilde hitap edebilmek ve etkin bir iletişim kurabilmek için anahtar rol oynamaktadır. Bu çalışmada, reklam görselleri üzerinden kadın ve erkekler arasındaki görsel 
odaklanma farklılıklarının ve dolayısı ile kadın ve erkek tüketicilere ulaşmada görsellerin hangi öğelerinin ve bölgelerinin daha büyük önem teşkil ettiğinin tespit edilmesi amaçlanmıştır.

Isı haritaları, ortalama odaklanma yüzdesi ve toplam odaklanma süresi verilerine göre, kadınlar temel olarak insan formu ve yüze odaklanma eğilimi gösterirken, erkeklerin ise daha geniş bir alanı tarayarak uzamsal dikkat (Kimura, 1992) eğilimi gösterdikleri tespit edilmiştir. Farklı literatürlerdeki çalışmalarda, kadın ve erkeklerin bu eğilimlerine ilişkin bulgulara rastlanmakla birlikte, bu farklılıkların pazarlama alanında ve reklam görselleri üzerinde test edildiği çalışmaların sayısı yok denecek kadar azdır. Bu nedenle, araştırma bulguları hem ulusal hem de uluslar arası yazına önemli katkılarda bulunmaktadır.

Kadınların yüze odaklanması, evrimsel psikoloji literatüründe annenin bebek bakımı ve dolayısı ile türün devamlılığına ilişkin rolü ile ilişkilendirilmektedir (Alexander, Wilcox, ve Woods, 2009; Burkart, Hrdy, ve Van Schaik, 2009). Öte yandan, kadınların sosyal yönlü düşünce yapıları ve dünyayı bu yönde tercüme etmeye yönelik eğilimleri (Kaplan, 1978), duygu yönetimi süreçleri ve yüze bakmak sureti ile diğer insanların duygularını anlama becerilerinin erkeklere kıyasla daha yüksek olması (McClure, 2000) gibi bulgular da, kadınların yüze odaklanmasına ilişkin neden ve/veya sonuç teşkil edebilecek ve yine evrimsel psikoloji literatürü ile ilişkilendirilebilecek bulgulardır. Ayrıca kadınların sadece yüzleri daha uzun incelemenin dışında, okumaya ve görmeye başladıkları alanı tamamlama, bitirme konusunda da erkeklere göre daha başarılı oldukları görülmektedir. Erkekler ise hızlıca görseldeki bütün öğeleri taramakta ve daha kısa süre odaklanma göstermektedirler.

Diğer yandan, erkeklerin kadınlara kıyasla logolara daha yüksek oranlarda ve daha uzun süre, metinlere ise daha az odaklandıkları tespit edilmiştir. Kadınlar ise metinlere odaklanmakta, ve bir metni tamamladıktan sonra diğer bölgelere geçme eğilimi göstermektedirler. Bu bulgular ambalaj ve etiket tasarımına ilişkin olarak gerçekleştirilen önceki çalışmaları da doğrular niteliktedir (Orquin and Scholderer, 2011; Graham and Jeffery, 2012). Bilişsel becerilerin kadın ve erkeklerde cinsel dimorfizm (çiftyapılılık) gösterdiği bilinmektedir (Bell ve diğerleri, 2005). Bu bağlamda, kadınların sözel akıl (Vogt, 2002), sözel yetenek testleri ve sözel nesne hafızası (Wegesin, 1998) gibi kelime ve metinlerle doğrudan alakalı olan görevlerde, erkeklerin ise mekansal yetenek testleri ve uzam rotasyonu gibi mekan ile alakalı ve geniş bir alanın taranması ve tasarlamasını gerektiren görevlerde daha başarılı oldukları tespit edilmiştir (Robert ve Ohlman, 1994; Kimura, 1996). Benzer şekilde kadınların yüz tanıma gibi epizodik hafıza görevlerinde erkeklere kıyasla daha iyi performans gösterdikleri bilinmektedir (Herlitz ve diğerleri, 1997). Bu bilişsel farklılıklar, görsel odaklanmada ortaya çıkan farklılıkları teyit edici ve açıklayıcı niteliktedir. Dolayısı ile pazarlama iletişimi çalışmalarında kadın ve erkeklerin cinsel dimorfizmine ilişkin bulgulara yer verilerek, görsellerin her iki kitlenin odaklanma örüntüsüne uyumlu olacak şekilde tasarlanması büyük önem arz etmektedir. Örneğin kadınlara yönelik iletişim çalışmalarında vurgulanmak istenen mesajın odaklanmanın gerçekleşeceği yüz görselinin yakınında verilmesi, iletişim etkinliğinde önemli farklılıklar yaratabilecek anahtar bir bulgudur. Bu çalışmada olduğu gibi, pazarlama ve tüketici davranışları alanındaki çalışmaların farklı disiplinlerde gerçekleştirilen araştırmalardan 
beslenerek tasarlanması, söz konusu bulguların pazarlama dünyasında somut uygulamalara dönüşebilmesi açısından büyük önem taşımaktadır.

Son olarak, araştırma bulguları doğrultusunda ileride yapılacak akademik çalışmalardan bahsetmek faydalı olacaktır. Önceki çalışmalarda bireylerin genellikle hemcinslerinin yüzlerine daha fazla odaklanma gösterdikleri veya kadınların kadın erkek ayrımı olmaksızın tüm yüzlere daha fazla odaklandıklarına dair çelişkili bulgular elde edilmiştir. Benzer bir tablonun bu çalışmada da ortaya çıkmış olması, bu farklılıklara sebep olan detayların araştırılmasını gerektirmektedir. Örneğin, kadın ünlü görselinin ve çoklu uyaranların (logo, yazılar, ürün, slogan vb.) bulunduğu görselde, erkeklerin yüze daha fazla odaklandıkları ortaya çıkmıştır. Bu bulgu, çoklu uyaran etkisinden kaynaklanabileceği gibi, erkeklerin yazılı materyallere daha az odaklanma eğiliminde olmasından da kaynaklanmış olabilir. Öte yandan, bu gibi araştırmalarda görselin hedef kitlesinin de odaklanmaya ilişkin farklı bulgulara neden olabileceği tahmin edilmektedir. Örneğin söz konusu görselde hedef kitlenin kadınlar oluşu, kadınların yüzden ziyade metin ve ürün görseli ile ilgilenmesine, erkeklerin ise logo ve yüze odaklanmasına yol açmış olabilir. Söz konusu ihtimallerin bertaraf edilebilmesi için, bundan sonraki çalışmalarda her bir faktörün etkisinin ortaya çıkartılması amacı ile kontrollü deneyler planlanarak, odaklanma farklılıklarının hangi koşullar altında gerçekleştiğinin açıklanması amaçlanmaktadır.

\section{Kaynakça}

Alexander, G. M., Wilcox, T. ve Woods, R. (2009). Sex Differences in Infants' Visual Interest in Toys. Archives Of Sexual Behavior, 38(3), 427-433.

Armony, J. L. ve Sergerie, K. (2007). Own-Sex Effects in Emotional Memory for Faces. Neuroscience Letters, 426(1), 1-5.

Bayliss, A. P., Pellegrino, G. D. ve Tipper, S. P. (2005). Sex Differences in Eye Gaze and Symbolic Cueing of Attention. The Quarterly Journal of Experimental Psychology, 58(4), 631-650.

Bell, E. C., Willson, M. C., Wilman, A. H., Dave, S. ve Silverstone, P. H. (2006). Males and Females Differ in Brain Activation During Cognitive Tasks. Neuroimage, 30(2), 529-538.

Burkart, J. M., Hrdy, S. B. and Van Schaik, C. P. (2009). Cooperative Breeding and Human Cognitive Evolution. Evolutionary Anthropology: Issues, News, and Reviews, 18(5), 175-186.

Chandon, P., Hutchinson, W. ve Young, S. (2002). Do We Know what We Look At?: An Eye-tracking Study of Visual Attention and Memory for Brands at the Point of Purchase, 1, 2-41. Insead.

Chandon, P., Hutchinson, J. W., Bradlow, E. T. ve Young, S. H. (2009). Does In-Store Marketing Work? Effects of the Number and Position of Shelf Facings on Brand Attention and Evaluation at the Point of Purchase. Journal of Marketing, 73(6), 1-17.

Connellan, J., Baron-Cohen, S., Wheelwright, S., Batki, A. ve Ahluwalia, J. (2000). Sex Differences in Human Neonatal Social Perception. Infant Behavior and Development, 23(1), 113-118.

Connor, J. M. ve Serbin, L. A. (1977). Behaviorally Based Masculine-and Feminine-Activity-Preference Scales for Preschoolers: Correlates with Other Classroom Behaviors and Cognitive Tests. Child Development, 1411-1416.

Cross, J. F., Cross, J.ve Daly, J. (1971). Sex, Race, Age, and Beauty as Factors in Recognition of Faces. Attention, Perception, \& Psychophysics, 10(6), 393-396. 
Djamasbi, S., Tullis, T., Hsu, J., Mazuera, E., Osberg, K. ve Bosch, J. (2007). Gender Preferences in Web Design: Usability Testing through Eye Tracking. AMCIS 2007 Proceedings, 133.

Eisenberg, N., Murray, E. ve Hite, T. (1982). Children's Reasoning Regarding Sex-Typed Toy Choices. Child Development, 81-86.

Fox, R. J., Krugman, D. M., Fletcher, J. E., ve Fischer, P. M. (1998). Adolescents' Attention to Beer and Cigarette Print Ads and Associated Product Warnings. Journal of Advertising, 27, 57-68.

Graham, D. J. ve Jeffery, R.W. (2012). Predictors of Nutrition Label Viewing During Food Purchase Decision Making: An Eye Tracking Investigation. Public Health Nutrition, 15(2), 189-197.

Herlitz, A., Nilsson, L. G. ve Bäckman, L. (1997). Gender Differences in Episodic Memory. Memory \& Cognition, 25(6), 801-811.

Kaplan, H. B. (1978). Sex Differences in Social Interest. Journal of Individual Psychology, 34(2), 206-209.

Kimura, D. (1992). Sex Differences in the Brain. Scientific American, 267(3), 118-125.

Kimura, D. (1996). Sex, Sexual Orientation and Sex Hormones Influence Human Cognitive Function. Current Opinion in Neurobiology, 6(2), 259-263.

Lewin, C. ve Herlitz, A. (2002). Sex Differences in Face Recognition-Women's Faces Make the Difference. Brain and Cognition, 50(1), 121-128.

Lohse, G. L. (1997). Consumer Eye Movement Patterns on Yellow Pages Advertising. Journal of Advertising, 26(1), 61-73.

Lutchmaya, S. ve Baron-Cohen, S. (2002). Human Sex Differences in Social and Non-Social Looking Preferences, at 12 Months of Age. Infant Behavior and Development, 25(3), 319-325.

Lutchmaya, S., Baron-Cohen, S. ve Raggatt, P. (2002). Foetal Testosterone and Eye Contact in 12-Month-Old Human Infants. Infant Behavior and Development, 25(3), 327-335.

Martin, C. L., Ruble, D. N. ve Szkrybalo, J. (2002). Cognitive Theories of Early Gender Development. Psychological Bulletin, 128(6), 903.

McClure, E. B. (2000). A Meta-Analytic Review of Sex Differences in Facial Expression Processing and Their Development in Infants, Children, and Adolescents. Psychological Bulletin, 126(3), 424-453.

McGuinness, D. ve Symonds, J. (1977). Sex Differences in Choice Behaviour: The Object-Person Dimension. Perception, 6(6), 691-694.

Moss, G. ve Colman, A. M.(2001). Choices and Preferences: Experiments on Gender Differences. Brand Management, 9(2), 89-98.

Moss, G., Gunn, R. ve Heller, J. (2006). Some Men Like It Black, Some Women Like It Pink: Consumer Implications of Differences in Male and Female Website Design. Journal of Consumer Behavior, 5(4), 328-341.

Orquin, J. ve Scholderer J. (2011). Attention to Health Cues on Product Packages, http://recil.grupolusofona. pt/handle/10437/2311

Pieters, R. ve Warlop, L. (1999). Visual Attention During Brand Choice: The Impact of Time Pressure and Task Motivation. International Journal of Research in Marketing, 16(1), 1-16.

Pieters, R., Warlop, L. ve Wedel, M. (2002). Breaking through the Clutter: Benefits of Advertisement Originality and Familiarity for Brand Attention and Memory. Management Science, 48(6), 765-781.

Rayner, K. (1998). Eye Movements in Reading and Information Processing: 20 Years of Research. Psychological Bulletin, 124(3), 372.

Robert, M. ve Heroux, G. (2004). Visuo-Spatial Play Experience: Forerunner of Visuo-Spatial Achievement in Preadolescent and Adolescent Boys and Girls? Infant and Child Development, 13(1), 49-78. 
Robert, M. ve Ohlmann, T. (1994). Water-Level Representation by Men and Women as A Function of Rodand-Frame Test Proficiency and Visual and Postural Information. Perception, 23(11), 1321-1333.

Russo, J. E. ve Leclerc, F. (1994). An Eye-Fixation Analysis of Choice Processes for Consumer Nondurables. Journal of Consumer Research, 21(2), 274-290.

Schotter, E. R., Berry, R. W., McKenzie, C. R. ve Rayner, K. (2010). Gaze Bias: Selective Encoding and Liking Effects. Visual Cognition, 18(8), 1113-1132.

Stewart, A. J., Pickering, M. J. ve Sturt, P. (2004). Using Eye Movements During Reading as an Implicit Measure of the Acceptability of Brand Extensions. Applied Cognitive Psychology, 18(6), 697-709.

Taylor, M. J., Itier, R. J., Allison, T. ve Edmonds, G. E. (2001). Direction of Gaze Effects on Early Face Processing: Eyes-Only versus Full Faces. Cognitive Brain Research, 10(3), 333-340.

Tedesco, D., Chadwick-Dias, A. ve Tullis, T. (2004). Demographic Differences in Preferred Web Site Content. Aging by Design. Presentation at Bentley College, Waltham, Massachusetts.

Raaij, W. (1977). Consumer Information Processing for Different Information Structures and Formats. ACR North American Advances.

Vogt, P. (2002). The Physical Symbol Grounding Problem. Cognitive Systems Research, 3(3), 429-457.

Wedel, M. ve Pieters, R. (2000). Eye Fixations on Advertisements and Memory for Brands: A Model and Findings. Marketing Science, 19(4), 297-312.

Wedel, M. ve Pieters, R. (2008). A Review of Eye-Tracking Research in Marketing. in Review of Marketing Research (123-147). Emerald Group Publishing Limited.

Wegesin, D. J. (1998). Relation Between Language Lateralisation and Spatial Ability in Gay and Straight Women and Men. Laterality: Asymmetries of Body, Brain and Cognition, 3(3), 227-239.

Wright, D. B. ve Sladden, B. (2003). An Own Gender Bias and the Importance of Hair in Face Recognition. Acta Psychologica, 114(1), 101-114. 
